\title{
HUBUNGAN FENOMENA ALONE TOGETHER DENGAN INTERAKSI KELUARGA
}

\author{
Nabila Ashima Putri ${ }^{1,{ }^{*} a}$, Mulyati Mulyati ${ }^{1 \mathrm{~b})}$, dan Hamiyati Hamiyati ${ }^{1, \mathrm{c})}$ \\ ${ }^{1}$ Universitas Negeri Jakarta Jalan Rawamangun Muka, Jakarta Timur, 13220, Indonesia, \\ Telepon (021)4890046 Fax 47864808
}

Email : ${ }^{* a)} \underline{\text { nabilaashima4@gmail.com, }}{ }^{\text {b) }}$ imoel.mulyati@gmail.com, ${ }^{\text {c) }}$ atihamiyati@gmail.com

\begin{abstract}
Abstrak
Teknologi komunikasi yang berkembang dengan cepat di era globalisasi membuat banyak masyarakat menggunakan gadget sebagai salah satu media atau sarana berkomunikasi dan mencari hiburan. Tidak hanya orang dewasa melainkan remaja dalam usia sekolah. Meningkatnya penggunaan gadget yang berlebih pada orang tua dan remaja tersebut menimbulkan suatu fenomena baru di dalam keluarga, yang disebut dengan alone together. Akibat dari fenomena tersebut adalah berkurangnya intensitas interaksi di dalam keluarga, khususnya interaksi antara orang tua dan anak. Penelitian ini bertujuan untuk memberikan gambaran hubungan fenomena alone together dengan interaksi keluarga. Penelitian ini dilakukan di SMP Negeri 209 Jakarta Timur. Pengambilan sampel dalam penelitian ini menggunakan simple random sampling. Metode penelitian ini menggunakan metode survey. Jumlah sampel dalam penelitian ini sebanyak 185 siswa aktif di SMP Negeri 209 Jakarta Timur. Perhitungan data menggunakan SPSS 2.2 dan Excel. Uji prasyarat pada penelitian ini menggunakan uji normalitas kolmogorov smirnov dan hasil yang ada menyatakan bahwa data tidak berdistribusi dengan normal, maka penelitian ini mengunakan perhitungan non parametrik. Uji hipotesis data yang digunakan adalah korelasi dengan hasil $r_{\text {hitung }}>r_{\text {tabel }}$ yaitu sebesar $-0,353>0,138$. Hasil uji t dengan taraf signifikasi 0,05 diperoleh yaitu $r_{\text {hitung }}>r_{\text {tabel }}-5,688$ $>1,97$ hal ini menjelaskan bahwa terdapat korelasi negatif dan hubungan yang signifikan antara fenomena alone together dengan interaksi keluarga. Alone together memberikan sumbangan efektif terhadap interaksi keluarga sebesar $15 \%$, sedangkan sisanya $85 \%$ ditentukan oleh faktor lain yang tidak diteliti.
\end{abstract}

Kata Kunci : Alone Together, Gadget, Interaksi Keluarga, Orang Tua, Remaja

\section{The Relationship of Alone Together Phenomenon With Family Interaction}

\begin{abstract}
Communication technology developing rapidly in this globalization era makes a lot of people use the gadget as one of any media to communicate and entertain. Not only adults but a teenager in school age. That increasing use of gadget for parent and teenager cause a new phenomenon in the family called alone together. This research aims to describe the effect of alone together phenomenon on family interaction. This research was conducted at 209 Junior High School, East Jakarta. This data research is processed by using a simple random sampling technique and this research use a survey method. Total samples 185 active students in 209 Junior High School, East Jakarta. This whole research data are using SPSS 2.2 and Microsoft Excel. The prerequisite test in this study uses Kolmogorov Smirnov for the normality test and the result shows that data are not normally distributed. So the research uses non-parametric calculation. Result of correlation coefficient test are obtained $>$ that is equal to $-0,353>0,138$. Result of $t$-test with significance level
\end{abstract}


0,05 obtained $>$ that equal to $-5,688>1,97$ the result explains that there is a negative and significant correlation between alone together and family interaction. Alone together give $15 \%$ effective contribution to family interaction and the other $85 \%$ determined by other factors.

Keywords: Alone Together, Family Interaction, Gadget, Parent, Teenager

\section{PENDAHULUAN}

Orang tua memiliki peranan terpenting dalam keluarga. Pada hakikatnya, orang tua memiliki tugas utama untuk bertanggung jawab atas pendidikan, pengasuhan, dan pemberian bimbingan pada anak-anaknya. Pendidikan berawal dari orang tua yang merupakan guru sekaligus role model utama bagi anak. Anak akan melewati beberapa fase di dalam hidupnya dan agar optimal dalam melewati fase fase tersebut, orang tua harus siap terlibat dalam mengantarkan anak anak mereka ke dalam kehidupan bermasyarakat.

Anak akan melewati beberapa fase di dalam hidupnya salah satunya adalah fase remaja. Pada fase tersebut perubahan perubahan yang akan dihadapi berupa biologis, psikologis, dan sosial ekonomi (Putro, 2017). Menurut World Health Organization (WHO) dalam membagi kriteria remaja ke dalam dua bagian, yaitu remaja awal dimulai pada usia 12 - 16 tahun dan remaja akhir pada usia 17 - 25 tahun.

Pada semua periode perkembangan remaja, memiliki kesulitan tersendiri, karena masa ini merupakan masa-masa sulit yang menjadi tantangan bagi remaja dan orang tuanya (Putro, 2017). Kesulitan itu dimulai pada fenomena remaja sendiri, contohnya adalah remaja yang lebih mudah terpengaruh oleh teman-temannya dibandingkan ketika mereka masih kanakkanak. Fenomena ini membuktikan bahwa pengaruh orang tua terhadap anak semakin rendah. Remaja berperilaku seakan mereka mempunyai kesenangan yang berbeda bahkan bertentangan dengan nilai-nilai yang ada di dalam keluarga remaja itu sendiri. Selain itu, penggunaan teknologi seperti gadget yang digunakan remaja secara terus menerus menjadi salah satu permasalahan baru di dalam keluarga, khususnya bagi orang tua.

Untuk menghindari terjadinya hal tersebut pada remaja, maka peran orang tua sangat dibutuhkan. Tetapi, suatu sikap yang sering terlihat pada orang tua sekarang adalah kurang memahami bahwa anaknya yang mulai beranjak remaja justru membutuhkan lebih banyak waktu dan perhatian untuk menciptakan hubungan timbal balik, hubungan komunikatif agar permasalahan-permasalahan yang dihadapi oleh remaja memperoleh bantuan, dan dukungan dari orang tua untuk mengatasinya (Pujianti, 2008).

Kurangnya interaksi antara orang tua dan remaja dapat mengakibatkan penurunan karakter pada remaja tersebut, karena orang tua sebagai tempat pengasuhan dan sosialisasi nilai karakter pada remaja berkurang (Pasaribu \& Magdalena, 2013). Permasalahan yang terjadi saat ini di kalangan remaja khususnya dalam bidang sosial, dan budaya, kehilangan identitas diri, terpengaruh budaya barat, serta masalah degradasi moral seperti kurang menghormati orang lain, tidak jujur sampai ke usaha menyakiti diri sendiri seperti narkoba, merokok (Pasaribu \& Magdalena, 2013).

Salah satu penyebab munculnya permasalahan pada remaja adalah dari kalangan keluarga, yaitu kurangnya perhatian, interaksi, dan kasih sayang yang didapat dari orang tua, sehingga remaja cenderung mencari perhatian di luar lingkungan keluarganya. Permasalahan keluarga yang semakin rentan akhir-akhir ini dikarenakan semakin melemahnya kualitas interaksi antara anggota keluarga sehingga memudarnya fungsi keluarga dalam melindungi anggotanya dari pengaruh pihak luar. Pengaruh luar terhadap keluarga semakin kuat akibat peningkatan teknologi komunikasi di era informasi globalisasi (Pujianti, 2008). 
Perkembangan teknologi komunikasi yang berkembang dengan cepat di era globalisasi ini membuat masyarakat banyak yang menggunakan gadget sebagai salah satu media berkomunikasi. Menurut perusahaan survei eMarketer pengguna gadget tahun 2016 mencapai 65,52 juta. Tahun 2017 ada 74,9 juta, tahun 2018 dan 2019 akan terus berkembang mulai dari 83,5 juta hingga 92 juta pengguna gadget. Berdasarkan usia, pengguna gadget terbanyak adalah usia 12-24 tahun yaitu sebanyak 31 persen khususnya pada remaja. Selain itu Sekolah Tinggi Sandi Negara (STSN) melakukan riset tentang penggunaan internet dan hasilnya membuktikan bahwa sebanyak $64 \%$ di kalangan remaja (Arifin, 2015). Remaja yang lahir pada taun 1995-2010 atau saat ini kita kenal dengan sebutan Generasi Z. Pada tahun tersebut teknologi terutama internet dan gadget sudah lebih berkembang dibandingkan dengna generasi sebelumnya, maka tidak dapat dipungkiri bahwa Generasi Z sudah terbiasa atau bahkan dikenalkan dengan berbagai bentuk gadget (Adiansah, 2019).

Alone together adalah suatu keadaan dimana individu berkumpul tetapi sibuk dengan penggunaan gadget mereka dan mengurangi interaksi langsung antar muka (Drago, 2015). Sedangkan pada remaja terdapat dampak negatif penggunaan gadget, yaitu remaja yang dapat mengalami kecanduan terhadap gadget, remaja menjadi lambat dalam memahami pelajaran, dan juga akan beresiko terhadap perkembangan psikologis. Penggunaan gadget yang berlebihan juga dapat mengubah prilaku dari remaja tersebut, contoh beberapa prilaku yang ditunjukkan ialah, introvet, selfi, sulit konsentrasi pada dunia nyata, anti sosial, dan penyimpangan sosial (Arifin, 2015).

Alone together merupakan istilah khas yang melekat pada orang-orang yang sikap dan perilakunya dipengaruhi oleh keberadaan teknologi komunikasi, seperti internet (Turkle, 2011). Perilaku ini menunjukkan masalah yang kita anggap sebagai penyakit, yang selanjutnya orang menjadi terisolasi dari realita karena teknologi mendominasi dan membuat individu menjadi kurang peka terhadap sekitar. Kemajuan teknologi ini memiliki dampak drastis pada cara individu berkomunikasi (Drago, 2015). Remaja dan orang tua menghabiskan lebih banyak waktu di lokasi yang sama, tetapi tidak mengubah waktu yang mereka habiskan untuk melakukan kegiatan bersama (Mullan, 2019).

Hasil studi pendahuluan yang dilakukan di SMP Negeri 209 Jakarta, ditemukan terdapat permasalahan menyangkut penggunaan gadget pada remaja yang dilakukan di sekolah. Masih banyaknya siswa yang membawa handphone ke sekolah meskipun sudah terdapat aturan yang melarang membawa gadget tersebut. SMP Negeri 209 Jakarta rutin melakukan inspeksi setiap minimal seminggu sekali, untuk melakukan penyitaan terhadap barang selain kebutuhan sekolah. Barang yang paling banyak disita adalah handphone. Hasil tersebut membuktikan masih banyaknya remaja yang tidak dapat lepas dari handphone. Ini membuktikan terdapat indikasi alone together pada remaja di sekolah tersebut. Sejalan dengan teori yang disebutkan (Mullan, 2019) fenomena alone together ini semakin terjadi dengan bertaburnya fitur media sosial (medsos) yang memberikan setiap kesenangan yang hingga membuat setiap orang merasa lupa diri dengan kehidupan nyata di sekitarnya terutama waktu di dalam keluarga.

Hasil temuan lainnya terdapat 3-5 orang tua siswa di setiap kelas VII dan VIII yang tidak mengambil rapor anaknya. Setelah melakukan wawancara dengan wali kelas, alasan yang diungkapkan orang tua adalah tidak mendapatkan informasi tersebut dari anak. Hal ini membuktikan bahwa interaksi yang terjadi antara orang tua-anak kurang. Bukti ini sejalan dengan penelitian yang dilakukan oleh (Drago, 2015) menunjukkan bahwa teknologi memiliki efek negatif baik kualitas dan kuantitas komunikasi tatap muka. Fenomena ini sangat relevan dengan kejadian yang ada di sekitar kita sekarang. Maka dari itu penelitian ini diharapkan dapat memberikan sumbangan untuk pengembangan teori ilmu keluarga terutama interaksi keluarga dan psikologi anak. Juga menambah pengetahuan dan pemahaman mengenai fenomena alone together yang terjadi di masyarakat. Untuk orang tua, hasil dari penelitian ini diharapkan dapat memberikan pengetahuan dan gambaran baru bagi orang tua mengenai 
fenomena alone together dan pentingnya membangun interaksi yang baik antara orang tua dengan anak, khususnya pada usia remaja. Untuk remaja sendiri dapat memberikan wawasan kepada remaja untuk dapat bertindak dalam pemenuhan hak - hak mereka dari orang tua untuk mendapatkan perhatian dan kasih sayang dan tidak addicted terhadap gadget dan untuk masyarakat dapat memahami tentang pengertian dari fenomena alone together dan dapat mengantisipasi terjadinya fenomena ini di dalam keluarga.

Berdasarkan studi pendahuluan dan uraian latar belakang di atas tersimpan harapan akan orang tua yang lebih banyak menjalin interaksi dengan anak. Oleh karena itu peneliti meyakini bahwa penelitian ini penting untuk dilakukan sebagai dasar dalam mengetahui seberapa besar intensitas interaksi di dalam keluarga, terutama interaksi antara orang tua dan anak serta mengetahui apakah fenomena alone together ada di dalam keluarga, serta perlunya tindakan antisipasi untuk mencegah fenomena ini terjangkit lebih jauh. Maka dari itu peneliti mengangkat judul "Hubungan Fenomena Alone Together Dengan Interaksi Keluarga (Studi Kasus di SMP Negeri 209 Jakarta)".

\section{METODOLOGI PENELITIAN}

Hasil penelitian yang disajikan dalam artikel ini merupakan hasil dari penelitian yang berjudul "Hubungan Fenomena Alone Together Dengan Interaksi Keluarga". Kegiatan penelitian yang dilakukan merupakan penelitian kuantitatif dimana secara teoritik penelitian kuantitatif menekankan analisisnya pada data-data yang berbentuk kuantitas, berbentuk angka atau kualitas yang diangkakan. Penelitian ini dilakukan di SMP Negeri 209 Jakarta yang bertempat di Jalan Raya Inpres, Kampung Tengah Jakarta Timur. Waktu penelitian ini dilaksanakan pada bulan Januari 2020.

Tujuan yang ingin dicapai dalam penelitian ini adalah mengetahui apakah terdapat hubungan fenomena alone together dengan interaksi di dalam keluarga, dengan studi kasus yang dilaksanakan di SMPN 209 Jakarta. Untuk metode yang digunakan dalam penelitian ini adalah survey. Penelitian juga ini menggunakan kuisioner tertutup yang dibagikan kepada siswa. Hasil perhitungan menggunakan skala likert. Adapun populasinya adalah berjumlah 379 siswa/l kelas VII dan VIII SMP Negeri 209 Jakarta Timur dan sampel sebanyak 185 siswa/I dengan rentang usia 13-15 tahun yang menurut WHO termasuk ke dalam usia remaja awal. Pengambilan sampel dalam penelitian ini menggunakan rumus slovin dengan teknik probability sampling yaitu simple random sampling. Karena teknik tersebut menganggap semua responden adalah homogen dan setiap populasi memiliki kesempatan/peluang yang sama untuk menjadi anggota sample, dan hasil sample sudah mengeneralisasi keseluruhan. Indikator yang digunakan dalam penelitian ini Teknik pengolahan dan analisis data menggunakan SPSS 2.2 dan Microsoft Excel.

Pernyataan untuk setiap butir kuisioner diukur menggunakan skala likert 1 sampai 4 poin, dengan skala terendah yaitu 1 dan tertinggi yaitu 4. Untuk variabel alone together menggunakan instrumen (Saleh \& Pitriani, 2018) yaitu perubahan sikap (asyik sendiri) dengan jumlah pernyataan 6 butir. Kemudian untuk variabel interaksi keluarga (Martiastuti \& Hasanah, 2018) yaitu interaksi diantara sub-sistem dengan jumlah pernyataan 12 butir dan aturan aturan keluarga dengan jumlah pernyataan 16 butir.

\section{HASIL DAN PEMBAHASAN}

Responden dalam penelitian ini adalah siswa dan siswi SMP Negeri 209 Jakarta kelas VII dan VIII yang berusia 13-15 tahun. Berikut data siswa siswi: 
Tabel 1. Data Siswa Kelas VII dan VIII

\begin{tabular}{cccc}
\hline \multirow{2}{*}{ No } & Kelas & $\begin{array}{c}\text { Jumlah } \\
\text { Siswa }\end{array}$ & Persentase \\
\hline 1 & 7 & 98 & $53 \%$ \\
2 & 8 & 87 & $47 \%$ \\
& Jumlah & 185 & $100 \%$ \\
\hline
\end{tabular}

Usia responden pada penelitian ini berusia 13-15 tahun. Dengan total responden adalah 185 siswa. Siswa dengan usia 13 tahun sebesar $76 \%$, siswa dengan usia 14 tahun sebesar $22 \%$, dan usia 15 tahun sebesar $2 \%$.

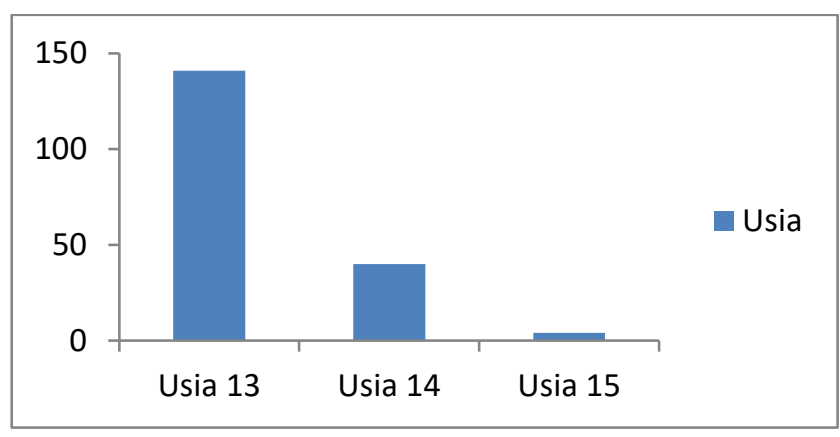

Gambar 1. Data Responden Berdasarkan Usia

Jenis kelamin responden yang terdiri dari siswa dan siswa aktif, adalah sebanyak 95 orang siswa laki-laki dan 95 orang siswa perempuan.

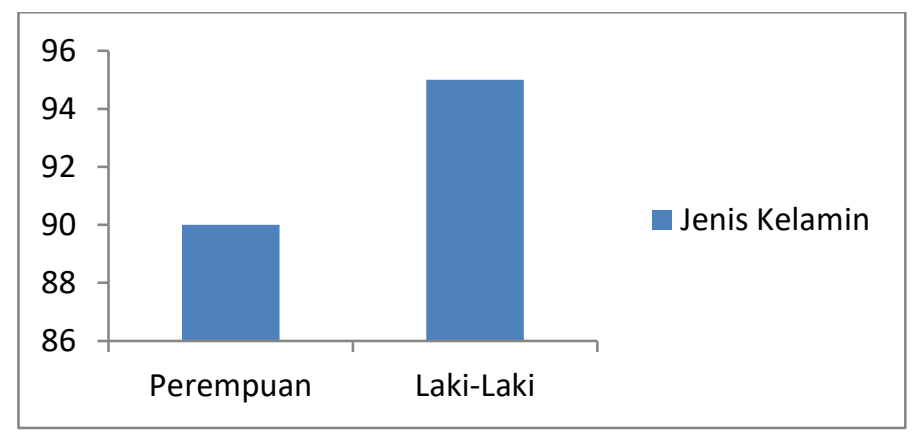

Gambar 2. Data Responden Berdasarkan Jenis Kelamin

\section{Variabel Alone Together}

Alone Together adalah suatu keadaan dimana sekelompok individu sibuk dengan dunianya, dikarenakan keberadaan teknologi dan membuat indivudu tersebut tidak acuh dengan sekitarnya. Alone together dapat diukur dengan berdasarkan faktor faktor alone together dalam Saleh \& Pitriani (2018). Hasil penelitian pada variabel alone together diperoleh sebesar $73 \%$ dimana hasil tersebut cukup tinggi. Hal ini membuktikan bahwa sebagian siswa mengalami fenomena alone together. Sesuai dengan pendapat Ikbal, (2018) bahwa teknologi secara negatif mempengaruhi hubungan orang tua dan anak, dan memunculkan fenomena yang kerap disebut alone together. Pendapat lain diutarakan oleh (Drago, 2015) bahwa teknologi secara negatif mempengaruhi hubungan orang tua dan anak. Selanjutnya dungkapkan oleh (Turkle, 2011) pada bukunya "technology is addictive when what it offers meets our human vulnerabilities" yang berarti teknologi menjadi candu ketika bertemu apa dengan kerentanan manusia atau apa yang manusia butuhkan. Dimensi 
dari alone together didapatkan berdasarkan faktor - faktor yang mempengaruhi fenomena ini. Hasil dari dimensi tersebut tertera di dalam tabel berikut:

Tabel 2. Dimensi Dari Alone Together

\begin{tabular}{|c|c|c|c|}
\hline No & Dimensi & Indikator & Hasil \\
\hline \multirow[b]{2}{*}{1} & \multirow{2}{*}{$\begin{array}{c}\text { Perubahan Sikap (Asyik } \\
\text { Sendiri) }\end{array}$} & Addicted dengan media sosial & \multirow[b]{2}{*}{$73 \%$} \\
\hline & & $\begin{array}{l}\text { Kepuasan menggunakan media } \\
\text { sosial }\end{array}$ & \\
\hline
\end{tabular}

Dimensi perubahan sikap (asyik sendiri) diperoleh persentase sebesar 73\%. Dalam dimensi ini terdapat 2 indikator yaitu: (1) addicted dengan media sosial dengan persentase sebesar $77 \%$ dan, (2) kepuasan dalam menggunakan media sosial, memiliki persentase sebesar $70 \%$. Diagram dimensi terdapat pada gambar di bawah ini:

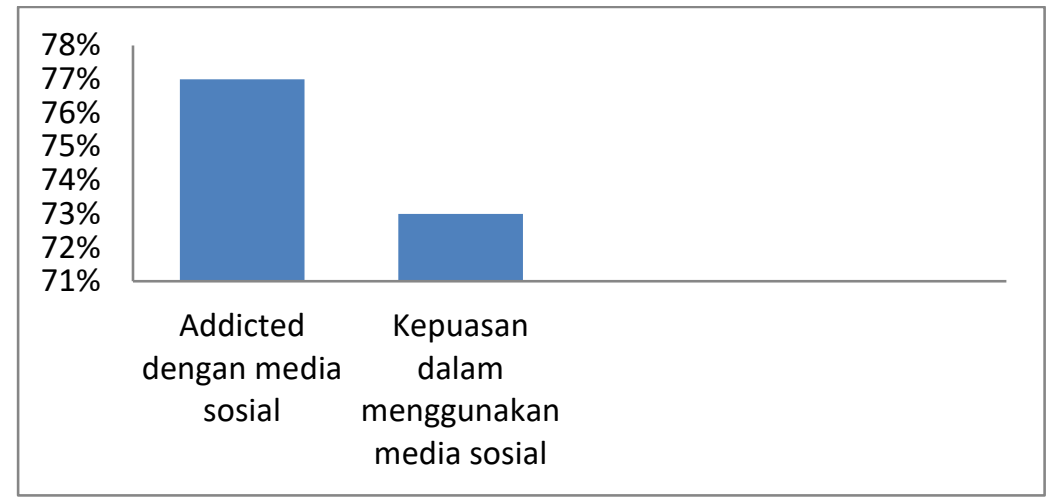

Gambar 3. Diagram Indikator Perubahan Sikap (Asyik Sendiri)

Berdasarkan hasil diagram di atas pada dimensi perubahan sikap (asyik sendiri) membuktikan bahwa perubahan sikap mempengaruhi terjadinya alone together di dalam keluarga. Pernyataan ini didukung oleh teori (Saleh \& Pitriani, 2018) yang mengatakan bahwa perubahan sikap mempengaruhi terjadinya fenomena alone together, karena efek yang ditimbulkan dari fenomena ini berupa sikap individu yang tidak peduli terhadap lingkungan sekitar, addicted terhadap dunia maya, dan bahkan akan kehilangan jati dirinya.

Pada variabel alone together terdapat 1 dimensi, dan hasil dari dimensi tersebut yaitu dengan persentase $73 \%$. Indikator tertinggi yaitu addicted dengan media sosial sebesar $77 \%$, yang kedua adalah rasa kepuasan dalam menggunakan media sosial sebesar $70 \%$.

Berdasarkan hasil penelitian yang dihitung, hasil menyatakan bahwa dimensi perubahan sikap (asyik sendiri) termasuk dalam kategori tinggi, karena sebagian banyak responden merasa bahwa dengan adanya media sosial sebagai teknologi membantu mereka untuk mengisi kekosongan dalam keseharian, dan merasa takut jika kehilangan koneksi dengan media sosial mereka. Hasil ini juga diperkuat dengan pernyataan dari (Saleh \& Pitriani, 2018) bahwa indikator yang mempengaruhi terjadinya fenomena alone together ini adalah perubahan sikap. Karena efek yang ditimbulkan dari fenomena ini berupa sikap individu yang tidak peduli terhadap lingkungan sekitar, addicted terhadap dunia maya, dan bahkan akan kehilangan jati dirinya. Hasil tersebut sesuai dengan pernyataan (Lubis, 2018), betapa gadget dan media sosial begitu menguasai kehidupan sehari-hari, sehingga gambaran tersebut menjadi pemandangan yang sering kita jumpai bahkan kita alami atau secara tidak sadar kita lakukan.

Sebuah penelitian lainnya yang dilakukan oleh (Drago, 2015) menunjukkan bahwa teknologi secara negatif mempengaruhi langsung antar individu, dalam konteks keluarga yakni 
hubungan orang tua dan remaja. Karena tidak dapat menghabiskan waktu berkualitas bersama keluarga mereka jika menghabiskan banyak waktu pada teknologi, sehingga mereka berhasil bergaul dengan dunia sekitar mereka namun gagal berhubungan dengan dunia dalam rumah mereka.

Tidak hanya pada remaja, sikap orang tua juga dapat berengaruh. Jika orang tua telah disibukkan oleh pekerjaan di luar rumah kemudian sesampainya di rumah juga disibukkan oleh perangkat gadgetnya dan anak juga melakukan hal yang sama karena orang tua yang menyediakan layanan tersebut, maka tidak ada kehangatan yang tercipta dalam lingkungan keluarga (Ikbal, 2018). Maka dari itu peran orang tua sangat dibutuhkan. Memberikan aturanaturan tegas kepada remaja dan mengawasi keberadaan remaja dalam penggunaan media sosial yang dimiliki.

Peranan orang tua di rumah sangat penting untuk mengontrol penggunaan gadget bagi remaja. Untuk mencegah terjadinya penggunaan gadget dengan intensitas yang sering untuk remaja orang tua dapat melakukan hal ini. Menurut (Lubis, 2018) yaitu pertama hush notpick one topic to talk. Ketika sedang berkumpul bersama teman-teman atau keluarga, jangan berdiam diri apalagi sibuk dengan gadget masing-masing. Melainkan, munculkanlah satu topik untuk menjadi bahan pembicaraan. Satu topik akan berlanjut dengan topik berikutnya dan seterusnya. Dengan demikian kita akan disibukkan dengan berkomunikasi secara langsung dengan orang-orang yang ada di sekitar kita (secara fisik). Hal ini tentu saja akan mengurangi pemakaian gawai dalam jangka waktu yang lama.

Kedua, habitual portrait of discipline and model dimana sasaran utama adalah orang tua. Tidak bisa dipungkiri bahwa anak cenderung melihat dan meniru orang tua. Tidaklah baik bagi orang tua meminta anaknya untuk tidak melakukan sesuatu, sedangkan orang tua tersebut melakukan hal yang yang mereka larang anaknya untuk berbuat. Misalnya, untuk tidak merokok sedangkan yang bersangkutan merokok. Demikian pula dengan pemakaian gadget.

Ketiga, hour and venue policy. Berlakukanlah peraturan kapan dan di mana saja gadget boleh digunakan. Peraturan ini lebih tepat diterapkan dalam lingkungan keluarga. Seluruh anggota keluarga meniatkan diri dan bersepakat untuk menetapkan jam-jam tertentu tidak memakai gadget misalnya mulai pukul 19.00 hingga 21.00 atau selama makan malam berlangsung. Bisa juga pada saat seluruh keluarga menghabiskan waktu bersama. Selain waktu, tempat pun bisa disepakati untuk tidak berhubungan dengan gadget. Misalnya, ketika berada di ruang keluarga.

Dunia sudah memasuki era baru yaitu era teknologi dan komunikasi. Perkembangan teknologi sekarang berkembang pesat, karena teknologi terus menciptakan berbagai macam jenis gadget yang memiliki klasifikasi sebagai gadget high technology. Penggunaan gadget ini dapat dilihat langsung di tempat-tempat umum seperti sekolah, stasiun, terminal, halte bahkan di bus sekalipun. Teknologi memang memiliki peluang untuk melakukan kegiatan keluarga bersama, tetapi juga pemisah di antara keluarga (Mullan, 2019). Misalnya ketika orang tua melakukan work from home yang tujuan utamanya adalah agar memiliki waktu untuk berinteraksi dengan keluarga, tetapi nyatanya melakukan kontak terus menerus dengan tempat kerja, semakin mengalihkan perhatian orang tua.

\section{Variabel Interaksi Keluarga}

Hasil penelitian pada variabel interaksi keluarga didapatkan dengan persentase sebesar $65 \%$ dengan kriteria sedang. Hal ini membuktikan bahwa hubungan interaksi di dalam keluarga tidak selalu baik. Sedangkan interaksi keluarga menjadi sangat penting karena kondisi tersebut akan memberikan kontribusi besar dalam melaksanakan kegiatan 
sehari-hari, pemecahan masalah, serta pengambilan keputusan. Pendapat ini juga sejalan dengan penelitian dari (Dewi, 2015) bahwa proses komunikasi dalam keluarga merupakan hal yang penting karena melalui komunikasi, interaksi dalam keluarga akan menjadi lebih baik. Interaksi keluarga adalah hubungan timbal balik antar anggota keluarga yang saling mempengaruhi, mengubah atau memperbaiki tingkah laku individu tersebut. Interaksi keluarga dapat diukur dengan bedasarkan bentuk - bentuk interaksi keluarga menurut Martiastuti \& Hasanah (2018).

Berdasarkan hasil perhitungan, dimensi dengan nilai persetase tertinggi terdapat pada dimensi interaksi diantara sub-sistem sebesar $65 \%$. Menyatakan bahwa interaksi individu mempengaruh keseluruhan interaksi di dalam keluarga. Pasaribu \& Magdalena (2013) mengatakan interaksi keluarga penting dilakukan karena kurangnya interaksi antara orang tua dan remaja dapat mengakibatkan penurunan karakter pada remaja tersebut, karena orang tua sebagai tempat pengasuhan dan sosialisasi nilai karakter pada remaja berkurang.

Tabel 3. Dimensi Dari Interaksi Keluarga

\begin{tabular}{|c|c|c|c|}
\hline No & Dimensi & Indikator & Hasil \\
\hline \multirow[b]{2}{*}{1} & \multirow{2}{*}{ Interaksi diantara sub-sistem } & Hubungan orang tua - anak & \multirow[b]{2}{*}{$65 \%$} \\
\hline & & Hubungan orang tua (ayah - ibu) & \\
\hline \multirow{4}{*}{2} & \multirow{4}{*}{ Aturan - aturan Keluarga } & $\begin{array}{l}\text { Adanya kerjasama dalam keluarga } \\
\text { untuk mencapai tujuan bersama } \\
\text { (aliansi) }\end{array}$ & \multirow{4}{*}{$63 \%$} \\
\hline & & $\begin{array}{l}\text { Adanya diskriminasi karena berbeda } \\
\text { paham (koalisi) }\end{array}$ & \\
\hline & & $\begin{array}{l}\text { Adanya keterlibatan orang ketiga di } \\
\text { luar keluarga (triangulasi) }\end{array}$ & \\
\hline & & $\begin{array}{l}\text { Adanya batasan batasan yang } \\
\text { diterapkan }\end{array}$ & \\
\hline
\end{tabular}

Variabel interaksi keluarga terdapat 2 dimensi yaitu interaksi diantara sub sistem dan aturan-aturan keluarga. Dimensi dengan hasil tertinggi berada pada interaksi diantara sub sistem, dengan persentase $65 \%$. Dengan urutan indikator tertinggi yaitu hubungan antara orang tua dan anak sebesar 69\% lalu hubungan antara orang tua (ayah-ibu) sebesar $62 \%$. Hasil ini membuktikan bahwa interaksi remaja sebagai responden, dengan orang tua tergolong sedang. Diagram dimensi terdapat pada gambar di bawah ini:

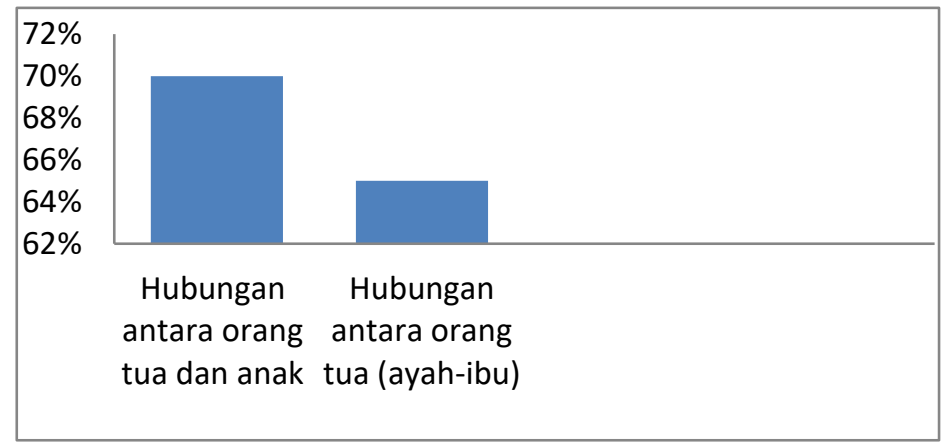

Gambar 4. Diagram Indikator Interaksi Diantara Sub-Sistem

Dimensi ini mengandung indikator yang cukup baik dan hasil penelitiannya cukup tinggi. Pada dimensi ini dapat diartikan bahwa interaksi diantara sub sistem orang tua dan anak menjadi hubungan interaksi yang paling penting. Karena interaksi antara orang tua dan remaja akan berpengaruh terhadap perkembangan remaja itu. Pernyataan ini sejalan dengan pedapat Pamungkas (2016) bahwa interaksi orang tua terhadap remaja memberikan pengaruh 
terhadap sikap remaja yang jika berkelanjutan akan berkembang menjadi karakter yang terbentuk pada diri remaja tersebut.

Dimensi aturan-aturan keluarga diperoleh persentase sebesar 61\%. Dalam dimensi ini terdapat 4 indikator yaitu: (1) adanya kerjasama dalam keluarga untuk mencapai tujuan bersama (aliansi) dengan persentase sebesar 62\%, (2) adanya diskriminasi dalam kerluarga karena berbeda paham (koalisi) memiliki persentase sebesar $59 \%$, (3) adanya keterlibatan orang ketiga di luar keluarga (triangulasi) memiliki persentase sebesar 59\% (4) adanya batasan-batasan yang diterapkan memiliki persentase sebesar $66 \%$. Diagram dimensi terdapat pada gambar di bawah ini:

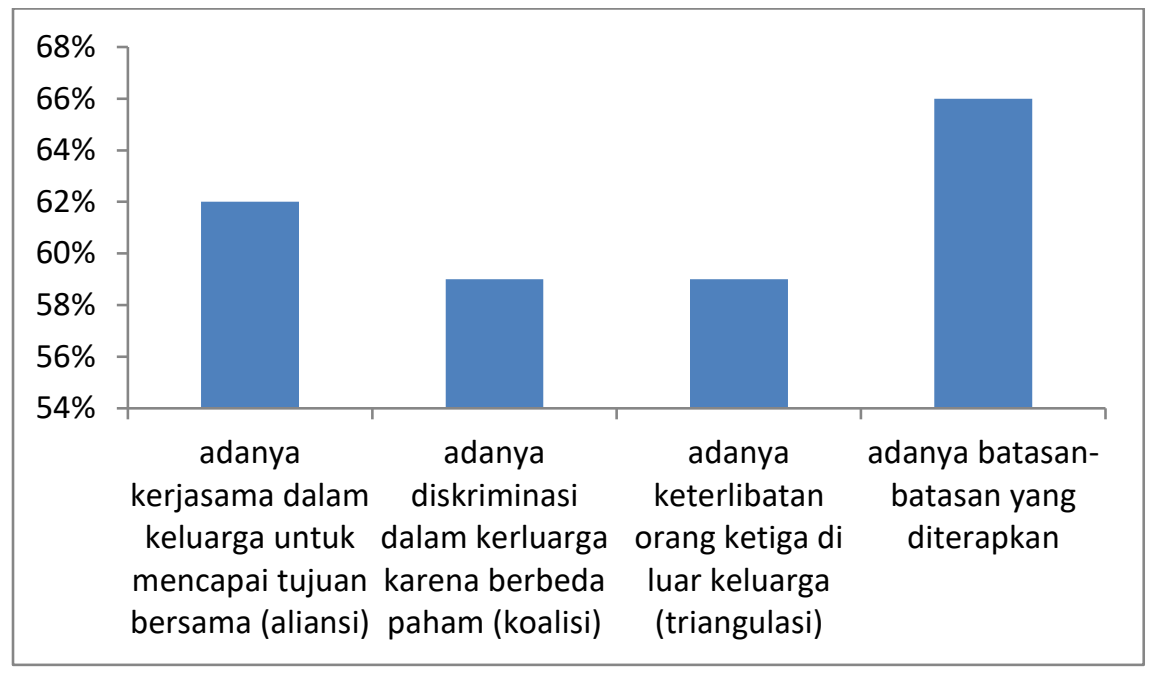

Gambar 5. Diagram Indikator Aturan-Aturan Keluarga

Jadi hasil yang dapat dijelaskan pada variabel interaksi keluarga, yaitu interaksi keluarga terutama pada hubungan orang tua dan anak menjadi sangat penting karena kondisi tersebut akan memberikan kontribusi besar dalam melaksanakan kegiatan sehari-hari, pemecahan masalah, serta pengambilan keputusan. Pendapat ini juga sejalan dengan penelitian dari Dewi (2015) bahwa proses komunikasi dalam keluarga (orang tua dan anak) merupakan hal yang penting karena melalui komunikasi, interaksi dalam keluarga akan menjadi lebih baik.

Orang tua merupakan pendidik pertama dan utama bagi anak, terutama pada remaja awal. Interaksi yang baik antara orang tua dan anak sangat penting karena akan mempengaruhi kepribadian dan jati diri dari remaja tersebut. Konsep dan pemahaman pada orang tua dan anak sangat dipengaruhi oleh interakasi dalam keluarga. Martiastuti \& Hasanah (2018) mengatakan bahwa pengalaman remaja sepanjang waktu bersama orang-orang yang mengenal mereka dengan baik, serta berbagai karakteristik dan kecenderungan yang mulai mereka pahami, merupakan hal-hal pokok yang mempengaruhi perkembangan konsep dan kepribadian sosial mereka. Sehingga karakter dan perilaku yang ditunjukan seorang remaja dari proses sosialisasi dan interaksi mereka dalam lingkungan terutama keluarga yang dimulai dari orang tua.

Dimensi dengan hasil rendah berada pada dimensi aturan-aturan keluarga dengan persentase sebesar $63 \%$. Dengan indikator terendah berada di indikator kerjasama dalam keluarga untuk mencapai tujuan bersama (aliansi) dengan persentase $55 \%$ sedangkan yang tertinggi berada pada indikator adanya diskriminasi dalam keluarga karena berbeda paham (koalisi) sebesar $71 \%$. Dari hasil terendah dan tertinggi di atas tersebut membuktikan bahwa masih kurangnya kerjasama orang tua dalam membangun interaksi yang baik dengan remaja, dan masih terdapat perbedaan paham orang tua dalam membuat aturan-aturan di dalam 
keluarga. Sedangkan orang tua merupakan subsistem yang utama di dalam keluarga. Kerjasama pada orang tua dibutuhkan untuk memberikan pengasuhan yang tepat bagi remaja.

Dalam keluarga terdapat beberapa sub sistem yang berbeda, pada keluarga inti, orang tua meduduki dua sub sistem yang berbeda sekaligus. Pertama ialah sub sistem sebagai pasangan suami-istri dan yang kedua adalah sub sistem sebagai orang tua. Dalam sub sistem pasangan, kedua orang tua digabungkn secara emosional, psikologis, dan seksual. Dalam konteks keluarga inti, sub sistem orang tua bertanggung jawab atas semua aspek pengasuhan pada anak.

Interaksi diantara sub sistem orang tua dan anak menjadi hubungan interaksi yang paling penting. Karena interaksi antara oran tua dan remaja akan berpengaruh terhadap perkembangan remaja itu. Pernyataan ini sejalan dengan pedapat Pamungkas (2016) bahwa interaksi orang tua terhadap remaja memberikan pengaruh terhadap sikap remaja yang jika berkelanjutan akan berkembang menjadi karakter yang terbentuk pada diri remaja tersebut.

Untuk variabel interaksi keluarga terdapat 2 dimensi yaitu interaksi diantara sub-sistem dan aturan-aturan keluarga. Dimensi dengan hasil tertinggi berada pada interaksi diantara sub-sistem, dengan persentase $65 \%$. Dengan urutan indikator tertinggi yaitu hubungan antara orang tua dan anak sebesar $69 \%$ lalu hubungan antara orang tua (ayah-ibu) sebesar $62 \%$. Hasil ini membuktikan bahwa interaksi remaja sebagai responden dengan orang tua tergolong sedang.

Interaksi keluarga, terutama pada hubungan orang tua dan anak menjadi sangat penting karena kondisi tersebut akan memberikan kontribusi besar dalam melaksanakan kegiatan sehari-hari, pemecahan masalah, serta pengambilan keputusan. Pendapat ini juga sejalan dengan penelitian dari (Dewi, 2015) bahwa proses komunikasi dalam keluarga (orang tua dan anak) merupakan hal yang penting karena melalui komunikasi, interaksi dalam keluarga akan menjadi lebih baik.

Orang tua merupakan pendidik pertama dan utama bagi anak, terutama pada remaja awal. Interaksi yang baik antara orang tua dan anak sangat penting karena akan mempengaruhi kepribadian dan jati diri dari remaja tersebut. Konsep dan pemahaman pada anak sangat dipengaruhi oleh interakasi dalam keluarga (Martiastuti \& Hasanah, 2018) mengatakan bahwa pengalaman remaja sepanjang waktu bersama orang-orang yang mengenal mereka dengan baik, serta berbagai karakteristik dan kecenderungan yang mulai mereka pahami, merupakan hal-hal pokok yang mempengaruhi perkembangan konsep dan kepribadian sosial mereka. Sehingga karakter dan perilaku yang ditunjukan seorang remaja dari proses sosialisasi dan interaksi mereka dalam lingkungan terutama keluarga yang dimulai dari orang tua.

\section{Hubungan Variabel Alone Together Dengan Variabel Interaksi Keluarga}

Hasil penelitian menunjukkan bahwa, terdapat hubungan antara variabel $\mathbf{X}$ dan variabel $Y$ dengan tingkat hubungan rendah. Korelasi berjalan ke arah negatif. Untuk uji t hasil yang didapatkan adalah $-5,688>1,97$, maka terdapat hubungan yang negatif dan signifikan. Hasil ini sesuai dengan pernyataan yang diungkapkan oleh (Lestari, 2015) penggunaan gadget yang tidak terkontrol yang dapat mengganggu proses interaksi sosial. Atau bahkan bisa jadi terisolasi dari lingkungan sosialnya, termasuk di dalam lingkungan sosial terdekatnya yaitu keluarga.

Penelitian ini dilakukan dengan responden remaja awal dari usia 13-15 tahun yang menduduki kelas VII dan VIII, karena pada usia dan masa awal remaja ini merupakan masamasa sulit yang menjadi tantangan bagi remaja itu sendiri dan orang tuanya (Putro, 2017). Selain itu menurut penelitian (Sherlyanita, 2016) pengguna internet dan gadget terbanyak ada 
pada usia 15 hingga 19 tahun. Remaja menggunakan internet untuk beberapa faktor kebutuhan yaitu untuk belajar, bermain sosial media, games, dan belanja online. Kebanyakan dari mereka menggunakan internet untuk bermain sosial media. Untuk menghindari terjadinya hal tersebut pada remaja, maka peran orang tua sangat dibutuhkan. Tetapi, suatu sikap yang sering terlihat pada orang tua sekarang adalah kurang memahami bahwa anaknya yang mulai menginjak remaja justru membutuhkan lebih banyak waktu dan perhatian untuk menciptakan hubungan timbal balik, hubungan komunikatif agar permasalahan-permasalahan yang dihadapi oleh remaja memperoleh bantuan, dan dukungan dari orang tua untuk mengatasinya (Pujianti, 2008).

Hasil perhitungan determinasi mendapatkan sebesar 15\%, maka fenomena alone together berkontribusi terhadap interaksi keluarga sebesar $15 \%$ seadangkan sisanya $85 \%$ disebabkan oleh faktor lain. Faktor pengasuhan orang tua juga dapat mempengaruhi interaksi, peraturan dan sikap yang ditunjukkan oleh orang tua akan menunjukkan sifat dan perilaku anak yang kemungkinan besar akan sama dengan orang tuanya. Kebiasaan-kebiasaan berperilaku tersebut yang kemudian akan mempengaruhi kemampuan anak, khususnya kemampuan dalam interaksi (Santrock, 2007).

Berdasarkan uraian di atas, alone together berhubungan dengan interaksi keluarga. Dalam hal ini yang memiliki peran paling penting adalah orang tua. Orang tua sebagai pendidik dan pengasuh tentu memiliki aturan dan batasan-batasan tertentu dalam keluarga, terutama dalam penggunaan gadget untuk remaja. Karena akan penggunaan yang berlebihan akan mempengaruhi interaksi antara orang tua dan anak. Orang tua diharapkan memiliki waktuwaktu tertentu dengan anaknya untuk menjalin interaksi dengan anak agar tercipta kehangatan, rasa nyaman dan aman, rasa saling berbagi antara orang tua dan anak.

Penelitian ini tidak sepenuhnya berjalan dengan lancar, tetapi terdapat keterbatasan dalam melakukan penelitian. Peneliti menyadari bahwa penelitian ini tidak sepenuhnya pada tingkat kebenaran mutlak. Sehingga tidak menutup kemungkinan diadakannya penelitian lanjutan untuk mendapatkan hasil yang lebih baik. Terdapat $85 \%$ variabel lain yang berkontribusi terhadap interaksi keluarga yang tidak diteliti oleh peneliti karena diluar fokus penelitian dan terbatasnya waktu dan tenaga. Minimnya literasi dan juga dimensi yang berkaitan dengan alone together.

\section{SIMPULAN DAN SARAN}

Berdasarkan penelitian yang telah dilakukan oleh peneliti, maka didapatkan hasil kesimpulan sebagai berikut. Pertama, hasil perhitungan variabel alone together memiliki persentase $73 \%$. Variabel memiliki satu dimensi yaitu perubahan sikap (asyik sendiri). Dimensi tersebut memiliki persentase sebesar $73 \%$.

Hasil perhitungan variabel interaksi keluarga memiliki persentase 64\%. Variabel memiliki 2 dimensi yaitu (1) interaksi diantara sub-sistem, dan (2) aturan-aturan keluarga. Dimensi yang paling tinggi adalah interaksi diantara subsistem dengan persentase sebesar $65 \%$ dan dimensi yang lemah adalah aturan-aturan keluarga yaitu sebesar $63 \%$. Rendahnya aturan-aturan keluarga, dikarenakan kerjasama antara orang tua masih kurang.

Fenomena alone together terdapat hubungan dengan interaksi keluarga dengan hubungan yang negatif dan signifikan. Besarnya hubungan alone together dengan interaksi keluarga, dari hasil perhitungan uji analisis statistik adalah sebesar $15 \%$. sedangkan sisanya $85 \%$ ditentukan oleh variabel lainnya yang tidak diteliti.

Selain kesimpulan, saran juga menjadi penting untuk menjadi acuan bagi peneliti selanjutnya, berdasarkan kesimpulan peneliti memberikan saran sebagai berikut. Pertama 
bagi orang tua, untuk menghindari terjadinya fenomena alone together di dalam keluarga, orang tua sebaiknya menjalin interaksi yang baik dengan remaja dengan meluangkan waktu untuk sekedar menanyakan kegiatannya di sekolah ataupun di luar sekolah, mendengarkan curahan hati, serta menanamkan dan mengkomunikasikan aturan-aturan yang jelas di dalam keluarga kepada anak. Selain itu orang tua sebaiknya menciptakan suasana dan kondisi rumah yang nyaman dan harmonis, sehingga remaja merasa bahwa orang tua dan rumah adalah tempat sebenar benarnya ia akan pulang. Kedua, bagi remaja. Remaja juga harus terus terbuka kepada orang tua, mengkomunikasikan semua yang terjadi dengan orang tuanya. Karena bercerita kepada teman sebaya tidak selalu mendapatkan jalan keluar yang terbaik. Anak juga harus mematuhi aturan-aturan yang ada di dalam keluarga tersebut. Terakhir, bagi peneliti selanjutnya untuk memperbanyak literatur mengenai alone together serta variabel lain yang dapat mempengaruhi interaksi keluarga.

\section{UCAPAN TERIMA KASIH}

Pertama dan utama ucapan terima kasih diucapkan kepada Allah SWT yang telah memberikan rahmat dan hidayahnya sehingga peneliti dapat menyelesaikan penelitian ini hingga akhir. Kepada Ibu Dra. Hamiyati, M.Si selaku dosen pembimbing pertama dan lbu Mulyati, M.Si selaku dosen pembimbing kedua, yang telah sabar memberikan pengarahan, bimbingan, motivasi dan saran yang berguna sehingga penelitian ini dapat terselesaikan. Terakhir kepada Kepala Sekolah, murid-murid khususnya kelas VII \& VIII yang telah membantu dalam proses pengambilan data, dan seluruh warga SMP Negeri 209 Jakarta yang telah membantu dalam proses pengambilan data.

\section{DAFTAR PUSTAKA}

Adiansah, W. dkk. (2019). Person in Environment Remaja Pada Era Revolusi Industri 4.0. Jurnal Pekerjaan Sosial, 2 No. 1, 47-60.

https://doi.org/https://doi.org/10.24198/focus.v2i1.23118.g11304

Arifin, Z. (2015). Perilaku Remaja Pengguna Gadget: Analisis Teori Sosiologi Pendidikan. Jurnal Tribakti Pemikiran Keislaman, 26 No. 2, 287-316.

https://doi.org/https://doi.org/10.33367/tribakti.v26i2.219

Dewi, L. 'Adah. (2015). Pengaruh Interaksi Orang Tua-Anak Dan Pengambilan Keputusn Keluarga Terhadap Kenalakan Remaja. IPB.

Drago, E. (2015). The Effect of Technology on Face-to-Face Communication. Elon Journal, 13-19.

Ikbal, R. (2018). Waktu Berkualitas Antara Orang Tua dan Anak Di Era Digital. Universitas Muhamadiyah Surakarta.

Lestari, I. (2015). Pengaruh Gadget Pada Interaksi Sosial Dalam Keluarga. Universitas Padjajaran, 2 No. 2. https://doi.org/2442-4480

Lubis, P. (2018). Fenomena Alone Together, Oxymoron dan Refleksi Kekinian. Retrieved July 30, 2019, from kompasiana.com/andolubis/5baf473a6ddcae3f7e76e9d5/fenomenaalone-together-oxymoron-dan-refleksi-kekinian?page=all

Martiastuti \& Hasanah. (2018). Interaksi Keluarga. Depok: Karima.

Mullan, K. (2019). Changing Times Together? A Time-Diary Analysis of Family Time in the Digital Age in the United Kingdom. Journal of Marriage and Family, 795-811.

https://doi.org/10.1111/jomf.12564 
Pamungkas, H. W. (2016). Interaksi Orang Tua Dengan Anak Dalam Menghadapi Teknologi KOmunikasi Internet. Universitas Tanjungpura Pontianak.

Pasaribu \& Magdalena, R. (2013). Gaya Pengasuhan Permisif dan Rendahnya Sosialisasi Nilai Dalam Keluarga Beresiko Terhadap Penurunan Karakter Remaja. IImu Keluarga Dan Konsumen, 6 No. 3, 163-171. https://doi.org/1907 - 6037

Pujianti, D. (2008). Hubungan Interaksi Anak Dalam Keluarga Dengan Kecerdasan Emosional Siswa Kelas Bertaraf Internasional (Studi Kasus Di Sman 1 Bogor). Undergraduate Thesis IPB.

Putro, K. (2017). Memahami Perkembangan Masa Remaja. Ejournal.UinSuka.Ac.ld/Pusat/Aplikasia, 17, 25-32. https://doi.org/1411-8777

Saleh \& Pitriani. (2018). Pengaruh Media Sosial Instagram dan WhatsAppTerhadap Pembentukan Budaya "Alone Together." Komunikasi, 10 No. 2. https://doi.org/2528 2727

Santrock, J. (2007). Perkembangan Anak Edisi Ke-7. Jakarta: Erlangga.

Sherlyanita, A. K. (2016). Pengaruh dan Pola Aktivitas Penggunaan Internet serta Media Sosial pada Siswa SMPN 52 Surabaya. Information Systems Engineering and Business Intelligence, 2, No 1. https://doi.org/http://dx.doi.org/10.20473/jisebi.2.1.17-22

Turkle, S. (2011). Second Life: Computer and The Human Spirit,Alone Togeher Why We Expect More From Technology and Less From Each Other. New York: Perseus Book Group. 